\title{
Picture Based Problem Learning in Improving Children's Communication Skills
}

\author{
Kamtini \\ Department of Early Childhood Education \\ Universitas Negeri Medan, Indonesia \\ kamtini@unimed.ac.id
}

\author{
Damaiwaty Ray \\ Department of Early Childhood Education \\ Universitas Negeri Medan, Indonesia \\ damaiwaty@gmail.com
}

\author{
Salsabila Hasiana Tanjung \\ Department of Early Childhood Education \\ Universitas Negeri Yogyakarta, Indonesia \\ salsabilahasiana.2019@student.uny.ac.id
}

\begin{abstract}
The ability to communicate is one of the skills children have as individuals who live in the 4.0 era. The research aims to examine the implementation of learning by using pictures that have problems to improve communication skills in children. 70 children participated in this study. The study was conducted by observing the behavior that emerged during the eight times the study. There is a difference in each treatment given, namely the significant increase in ability at the meeting of two to four. These findings support learning innovation so that teachers can improve children's communication skills in a fun way.
\end{abstract}

Keywords: children, communication skills and pictures

\section{INTRODUCTION}

Early childhood education aims to develop all aspects of the child to have the optimal potential. Important skills in the 21st century is still relevant to life's pillars of four types. This includes learning to know, learning to do learning to be and learning to live together. The principles on these pillars have skills that need to be empowered in daily learning activities, such as critical thinking skills, problem solving, metacognition, communication skills, collaboration, innovation and creation, information literacy, and various other skills. Communication skills are skills that should be possessed by each individual, without exception by early childhood. Communication skills help children to be better prepared to enter their social lives [1].

Conveying ideas and ideas by children is a skill that must be possessed. Communication skills are a necessary part of the 21 st century. Currently, 21st century skills that are still less competent are oral and written communication, critical thinking and problem solving, work ethics and professionalism, the ability to work in teams and collaborate, work in in different groups, and the ability to use technology, as well as project management and leadership [2].

Thus, a survey conducted by the NACE (National Association of Colleges and Employers) in 2017 indicates that as many as $67.5 \%$ of children have low communication skills. Low communication skills can affect the ability to process information, difficulty integrating thoughts and speech, and difficulty adapting to the environment. These problems are things that become a serious concern in the problem of skills that should be possessed in the 21 st century now.

Stimulation given to children to improve communication skills can be through activities that include conditions or problems that are easy for children to encounter by including images related to the problem.
Thus, children are easier to express every appreciation. Although in other studies, treatment is given by using a flash card [3] but on the flashcard the child is asked to convey what the child sees on the card given to the child.

The ability to communicate is also one of the problem concerns that must be taken seriously to be able to become a successful person in facing various kinds of interests and problems in the 21st century era. With good communication skills, all interests will be easier to be erased. Both in terms of communicating in writing or in words. So that it should be honed from an early age. At an early age, children are still prone to problems in communication, reading and mathematics, so that it becomes a factor in children's problems as a teenager [4].

Children are given learning that accustoms children to be able to communicate well. Children who have good communication skills have intrapersonal intelligence and ability to solve problems well [5]. In the process of stimulation of communication skills for young children in dire need of a child's environmental role. Successful communication skills are very dependent on how the child's environment intervenes by supporting children when communicating, especially when children are experiencing frustration [6]. The environment in question can be in the form of learning conditions given to children. Like the use of images in the implementation of learning as a medium to convey learning objectives and stimulate children's abilities. Children who have the ability to present or explain well and static become a picture that the child's cognitive ability is also good [7].

The child will talk based on the process of understanding and analysis that the child has done. Thus, the results of children's presentations are the results of children's cognitive processes that are going well [8]. Indicators of communication skills seen from student activities which include verbal communication skills and non-verbal communication skills. Verbal communication 
includes conducting discussions, presenting the results of discussions, expressing opinions, answering questions, writing the final results of the discussion, good grammar, short speech, clear and easy to understand and clear audible voice. Verbal communication skills in children need to be sharpened every day through habituation activities.

\section{METHOD}

There are 70 child participants were used in this study. There are 47 girls and 23 boys. All children are generally 5-6 years old. Child age data is collected from school administration data which is used to create age variables with an average age of around 64 months. In this study included the role of teachers as many as 6 people.

The implementation of this research was carried out by providing pictures relating to problems that were easily encountered by children around. In this study, the image used is a picture of environmental cleanliness. The treatment given to the child is expected so that the child can explain and relate the pictures given to the environmental conditions in accordance with the pictures the child gives. The pictures used in this study include pictures of clean and dirty environments. The treatment was given eight times with different pictures and with different tasks. Data processing obtained from the results of research carried out by using a time series test. The test carried out serves to see the difference obtained in eight treatments.

\section{RESULTS AND DISCUSSION}

According to the data an answering research questions, analysis of communication skills is seen from the data processed by time series test data. Following are data from eight treatments given to children in terms of communication skills.

Table 1

Average Value of Communication Skills

\begin{tabular}{|c|c|c|}
\hline $\begin{array}{c}\text { Data } \\
\text { Treatment }\end{array}$ & $\begin{array}{c}\text { The Average Value of } \\
\text { Explaining Ability }\end{array}$ & Category \\
\hline 1 & 3,057 & Good \\
\hline 2 & 3,093 & Good \\
\hline 3 & 3,111 & Good \\
\hline 4 & 3,146 & Good \\
\hline 5 & 3,170 & Good \\
\hline 6 & 3,185 & Good \\
\hline 7 & 3,190 & Good \\
\hline 8 & 3,200 & Good \\
\hline
\end{tabular}

The average value of the ability to explain to children by doing treatment eight times. Based on the table that each treatment showed a significant increase, especially in the first to second treatment, then the third to fourth treatment. Even though the change in numbers is not as big as the achievement of other abilities, so in the eighth treatment the ability to compare in children is already.

\section{CONCLUSION}

Children's skills in communication require the right stimulus in accordance with the needs of early childhood. One stimulus that can be given to children is by providing fun learning media through learning models that can support learning goals. The pictures given to children should use images that have been and are easily encountered by children around the child's environment. By using the pictures provided, children can more easily express ideas and ideas in accordance with the topic of discussion

Children's skills will improve well if done repeatedly. Repetition and habituation done to children will train children to be more skilled, especially in communication skills. This research was supported by all kindergartens, teachers, students and parents of Medan City who participated in this research.

\section{REFERENCES}

[1] Loukatari, P., Matsouka, O., Papadimitriou, K., Nani, S., Grammatikopoulos, V. "The Effect of a Structured Playfulness Program on Social Skills in Kindergarten Children". International Journal of Instruction, 12(3), 2019. 237-252.

[2] Trilling, B. Fadel,C. " 21 st Century Skills, Learning for Life in Our Times". San Francisco, CA. 2009. John Willey \& Sons. Hartati, S. "Significant

[3] Sensory Stimulation Program Through the Use of Flash Card as Media of Toddler Language Development at PreKindergarten". In 1st Non Formal Education International Conference (NFEIC 2018). January 2019. Atlantis Press.

[4] Thapar, A., Heron, J., Jones, R. B., Owen, M. J., Lewis, G., \& Zammit, S. "Trajectories of change in self-reported psychotic-like experiences in childhoodand adolescence". Schizophrenia research, 140(1-3), 2012. 104-109.

[5] Challita, J., Chapparo, C., \& Hinitt, J. "Kindergartento Grade Six Syllabuses". Australian occupational therapy journal. Cognitive aspects of social competence in the current New South Wales. 2018

[6] McCormack, J., McLeod, S., McAllister, L., \& Harrison, L. J. "My speech problem, your listening problem, and my frustration: The experience of living with childhood speech impairment". Language, Speech, and Hearing Services in Schools, 41(4), 2010. 379-392.

[7] Berry, E. D., Waterman, A. H., Baddeley, A. D., Hitch, G. J., \& Allen, R. J. "The limits of visual working memory in children: Exploring prioritization and recency effects with sequential presentation". Developmental psychology, 54(2), 2018. 240

[8] Parks, M., \& Oslick, M. E. Goldilocks and the Engineers: "Developing science discourse and understanding with kindergarten students. Science and Children, 55(6), 2018. 66-72 